\title{
Techno-Economic Assessment of Installing a Reliable Renewable Energy System for Electric Power Generation at Koforidua Polytechnic
}

\author{
Isaac Kwasi Yankey ${ }^{1}$, Samuel Kwofie ${ }^{2}$, Godfred Kwame Abledu ${ }^{2}$ \\ ${ }^{1}$ Department of Energy Systems Engineering, Koforidua Polytechnic, Koforidua, Ghana \\ ${ }^{2}$ Department of Applied Mathematics, Koforidua Polytechnic, Koforidua, Ghana \\ Email address: \\ ikyankey@gmail.com (I. K. Yankey),rockstahus@yahoo.com (S. Kwofie), godfredabledu@gmail.com (G. K. Abledu) \\ To cite this article: \\ Isaac Kwasi Yankey, Samuel Kwofie, Godfred Kwame Abledu. Techno-Economic Assessment of Installing a Reliable Renewable Energy \\ System for Electric Power Generation at Koforidua Polytechnic. International Journal of Energy and Power Engineering. \\ Vol. 5, No. 3, 2016, pp. 133-140. doi: 10.11648/j.ijepe.20160503.17
}

Received: May 14, 2016; Accepted: May 28, 2016; Published: June 13, 2016

\begin{abstract}
Ghana has been experiencing a lot of power outages over the years, mainly due to the heavy reliance on hydroelectric power plants, poor maintenance culture for existing plants as well as rising energy demand for development. These shortages have hindered the smooth running of businesses and academic institutions in the country. Institutions therefore operate with Genset for 12 hours with huge operational cost. This work therefore seeks to technically and economically assess a reliable alternative power supply for Koforidua Polytechnic. The building used in this assessment is the engineering block, which has five (5) floors with a total energy consumption of $227.520 \mathrm{kWh} /$ day for lights and fans. Homer software for micro grid and distributed generation power system design and optimization (NREL Homer) was used to do the optimization and sensitivity analysis with daily average electric demand of $9.48 \mathrm{~kW}$ and peak power of $26.7 \mathrm{~kW}$ with July, August and December having the highest mean values. The designed Photovoltaic (PV) system consists of $70 \mathrm{~kW}$ monocrystalline PV modules of 250 $\mathrm{Wp}$ at a system voltage of $12 \mathrm{~V}$ with 111 batteries and $17 \mathrm{~kW}$ converter. The levelized Net Cost to install a renewable energy system (PV) divided by its expected time energy output of electricity from the optimized system at an annual real interest rate of ten $(10 \%)$ percent is GHC2.38/kW. For the PV system designed to reach "Grid Parity", the levelized cost of energy is estimated to be GHC2.03/kW with an annual real interest rate of six $(6 \%)$ percent.
\end{abstract}

Keywords: Nrel Homer, Photovoltaic, Electricity in Ghana, Energy System Design, Levelized Cost of Energy

\section{Introduction}

The role the sun plays in human life on this planet is invaluable and cannot be underestimated. Wherever you find yourself from the provision of food (Agriculture) to the provision of energy the sun is inevitable. Modern households, companies, academic institutions and public agencies depend on electricity for their activities making electricity a key factor for development.

In Ghana, apart from the national grid, which is mainly made up of hydroelectric power (1382MW) and thermal power $(1245 \mathrm{MW})$, very few options exist to supply electricity for residential and non residential use [1]. Alternative sources of energy such as wind, mini-hydro, solar and others are the options but they have not been exploited to a large extend due to Policy and Institutional barriers to these technologies [2].

\subsection{Solar Resource in Ghana}

Out of the alternatives energy resource mentioned, solar energy is the most promising resource due to the fact that solar radiation is predominantly everywhere in the country. Meteorological Service Department (MSD) and Kwame Nkrumah University of science and technology (KNUST) have measured the countries solar resource with instruments of very good accuracy [3]. The measurements revealed Wa in the Upper West region had the highest level of solar irradiation $\left(5.524 \mathrm{KWh} / \mathrm{m}^{2}\right.$-day) and Akim Oda in the eastern region recorded the lowest $\left(4.567 \mathrm{kWh} / \mathrm{m}^{2}\right.$-day $)$ for 10 years monthly average that was computed. May and August were 
recorded as the months with the highest $\left(5.897 \mathrm{KWh} / \mathrm{m}^{2}\right.$-day) and lowest $\left(4.937 \mathrm{kWh} / \mathrm{m}^{2}\right.$-day) level of irradiation in Wa in the Northern Region respectfully [3].

The latitude and longitude of Koforidua located in the Eastern Region are $6.0833^{\circ} \mathrm{N}$ and $0.2500^{\circ} \mathrm{W}$ with average monthly radiation values and clearness index imported from NREL HOMER legacy are in figure 1 [4]. This makes solar Photovoltaic technology among the other renewable energy technologies the most promising option for Ghana and can help raise the standard of living, support services, business and institutions such as Koforidua Polytechnic.

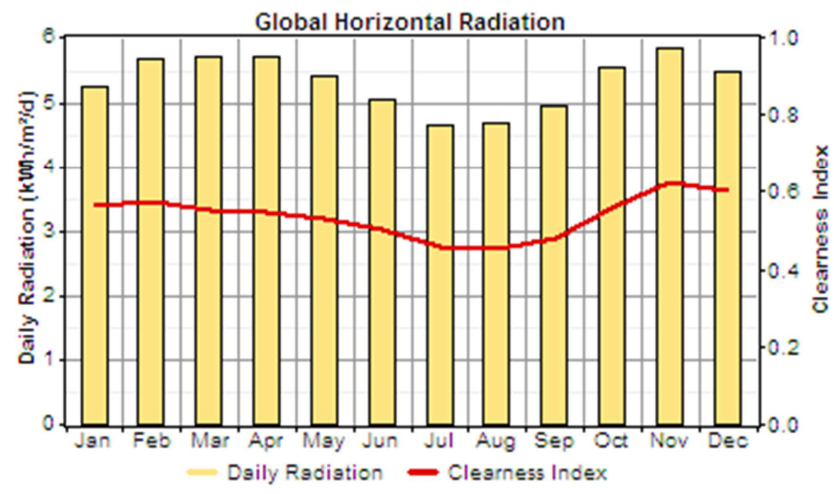

Fig. 1. Graph showing the monthly average solar radiation for Koforidua

Also, in a world where there is an outcry for the reduction of our carbon footprint and environmentally friendly energy technologies solar can play a very important role in achieving such reduction and targets in Ghana [5].

\subsection{The Energy Problem in Ghana}

Ghana has been experiencing a lot of power outages over the years, mainly due to the heavy reliance on hydroelectric power which is, more often than not, dependent on the country's rainfall pattern [1]. Also as a lower middle-income country, the demand for electric energy is on the rise and there is the need for strategic load forecasting such that power supply can be made available in time. Other problems such as maintenance and the frequent breakdown of the existing power plants have contributed to the power shortages. Electric power is rationed on a 12 hour bases for households, businesses, academic institutions and other public sectors. Koforidua Polytechnic in particular, spends large sums of money on diesel fuel to power generators due to these shortages. These monies can be used for other developmental projects in the school and also furnish the faculty of engineering laboratories should the polytechnic have a reliable alternative source of power at an affordable cost. Apart from the cost, this intermittent power hinders the smooth running of programs and activities in the faculty and also results in the breakdown of sensitive electronic appliances such as computers, printers, air conditioners, and laboratory equipment for the Polytechnic in general and the faculty in particular.

Ghana has set a renewable energy generation target of ten (10) percent to be achieved by 2020 as a means to combat negative environmental impacts associated with the unsustainable use of conventional fuels [6]. In order to achieve this targeted contribution of modern renewables in electricity generation, there is the need for an alternative energy source to provide a pollution free continuous supply of electricity in the country. Solar energy, being a renewable energy source, will provide energy without pollutants and greenhouse gas emissions. This can go a long way to help mitigate the adverse effects of global warming as well as contributing to energy security in the country [7].

\subsection{Reliable Electricity Supply to the Faculty of Engineering}

In view of the above issues, there is the need for an alternative energy source that would provide quality reliable supply of electricity to the Faculty of Engineering and subsequently all the other faculties in the Polytechnic. Photovoltaic technology is the most promising due to its resources among the options available for assessment. The main objective of the project is to assess a photovoltaic energy technology both technically and economically for the new block of the Faculty of Engineering-Koforidua Polytechnic. In order to achieve the above objective of the research, the load profile of the new engineering block was first determined, followed by design, simulation and optimization of the PV system and then the levelized cost of electricity of the PV system.

\subsection{Solar PV Installations in Ghana}

Ghana has embarked on rural electrification programs since the 1980's but with the high cost of extending the national grid to rural areas, islanders and the ever-increasing energy demand, solar lanterns and other PV technologies have been deployed in the country. [8] The energy commission in collaboration with KNUST have installed $4 \mathrm{kWp}$ grid-connected solar PV system, donated by the German state of North Rhine Westphalia to aid in research into grid-connected solar PV systems. There is very little information on the cost and as it was a donor-funded program to aid academic work, the economics was not the main focus. [9] The Volta River Authority (VRA) has developed a $5 \mathrm{MW}$ grid-connected solar PV power plant in the Northern region. This is a grid-connected system mainly to support the main energy generating company's supply but not a standalone system for an institution and hence different technical and economic requirements. [10]

\section{Data Collection Methods}

Fieldwork and standard method were used to collect data and NREL Homer legacy was used for the simulation, optimization and sensitivity analysis of the data. The fieldwork involved survey of the Faculty of Engineering block, analysis of the building and utility data, including the installed equipment in the faculty, occupancy and operating schedules. The major activities conducted were; Walk 
through method, Site survey and structured questionnaires.

The standard method involved quantification of energy uses and losses. For this method, detailed data computations and analysis were performed using standard engineering calculations and measurements. This was used to determine the total electrical energy demand in $\mathrm{kWh}$ for the building per day, month and year.

In the analysis different configurations were considered and the best option for the block was chosen based on the technical requirements of the building. Different annual real interest rates were used for the economic sensitivity analysis based on the chosen configuration and the tariff rates in the country.

\subsection{Results and Discussion}

Micropower system optimization software (Homer) was used to analyze the daily and monthly load profile for the building. The system was then optimized to determine the best configuration using the software.

Building Load Analysis:

The Faculty of Engineering block has five floors with roof dimensions of $227.7 \mathrm{~m} \times 29.3 \mathrm{~m}$. The detail installed electrical appliances; their rated power and operational hours are shown in appendix A1. The ground floor has an energy consumption of $23.280 \mathrm{kWh} /$ day. The first floor has the same quantity of electrical appliances as the second and third floors with the conference rooms replaced by two classrooms on the second floor, and a classroom and a library on the third floor respectively. The electrical load for each of the floor is shown in table 1 below. The total energy consumption for the block is $227.520 \mathrm{kWh} /$ day for lights and fans.

Table 1. Floors in the Block and respective energy consumption in $\mathrm{kWh} / \mathrm{day}$ for lights and fans.

\begin{tabular}{ll}
\hline Floor & Energy Consumption $(\mathbf{k W h} /$ day) \\
\hline Ground Floor & 23.280 \\
$1^{\text {st }}$ Floor & 52.840 \\
$2^{\text {nd }}$ Floor & 52.840 \\
$3^{\text {rd }}$ Floor & 52.840 \\
$4^{\text {th }}$ Floor & 45.320 \\
\hline
\end{tabular}

(Field data, 2016.)

Fig. 2. The average hourly electric load that needs to be met with daily average of $9.48 \mathrm{~kW}$, peak power of $26.7 \mathrm{~kW}$ and a Dmap showing July, August and December with the highest mean values.
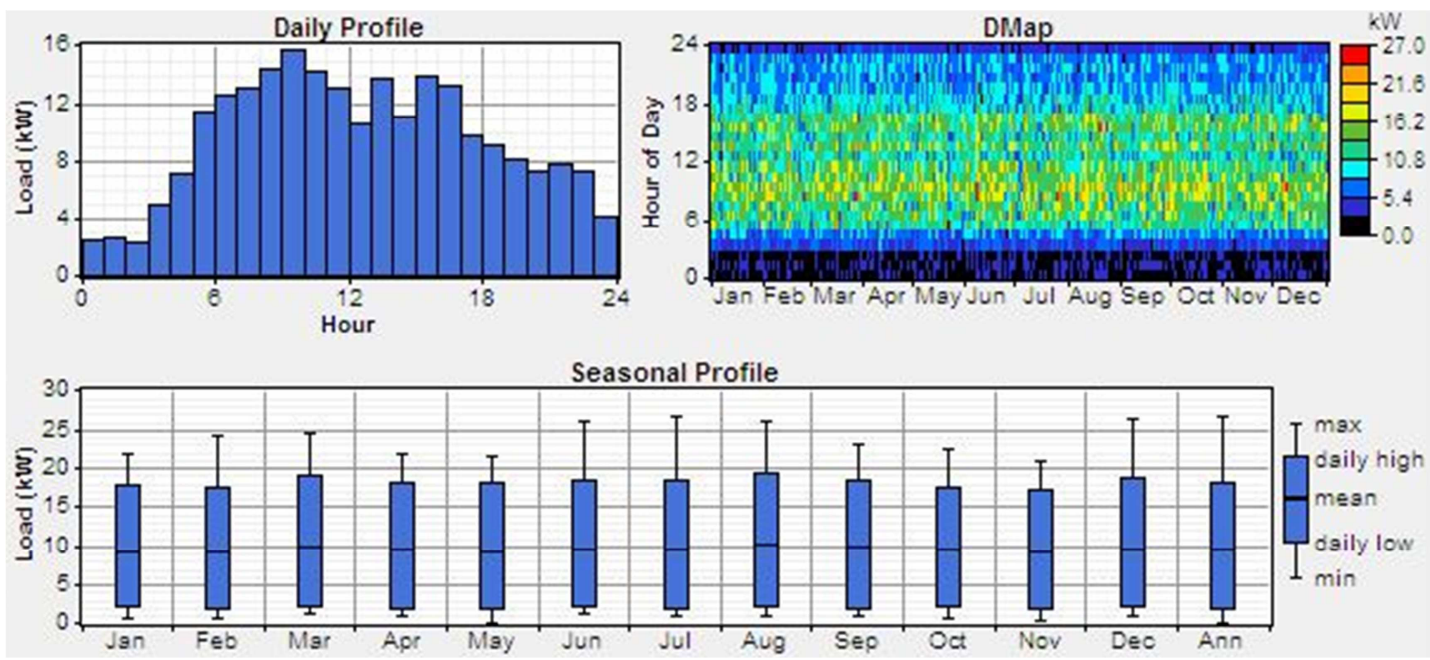

Fig. 2. The daily, seasonal and Dmap of the load profile (in $\mathrm{kW}$ ) of the Engineering block

\subsection{System Architecture}

A $350 \mathrm{Wp}$ monocrystalline silicon PV panel of fifteen percent (15\%) efficiency and dimensions $1.68 \mathrm{~m} \times 1.31 \mathrm{~m}$ from GB-Sol Ltd was selected. [11] The system has an installed battery capacity of $210900 \mathrm{~A}-\mathrm{hr}$, with estimated days of autonomy of 3 days, $12 \mathrm{~V}$ DC system and the maximum allowable depth of discharge (DOD) of 0.5 . The battery bank consists of Rolls Battery Surrette S4KS25P deep cycled 1900Ah batteries with efficiency of eighty percent (80\%) [4]. The required number of batteries is 3 batteries per string $x 37$ strings and is expected to operate for approximately 10 years before replacement. A Qingdao solar leading company ltd three phase $17 \mathrm{~kW}$ converter with efficiency of ninety percent (90\%) and a replacement life time of 15 years have been used in this study [12].

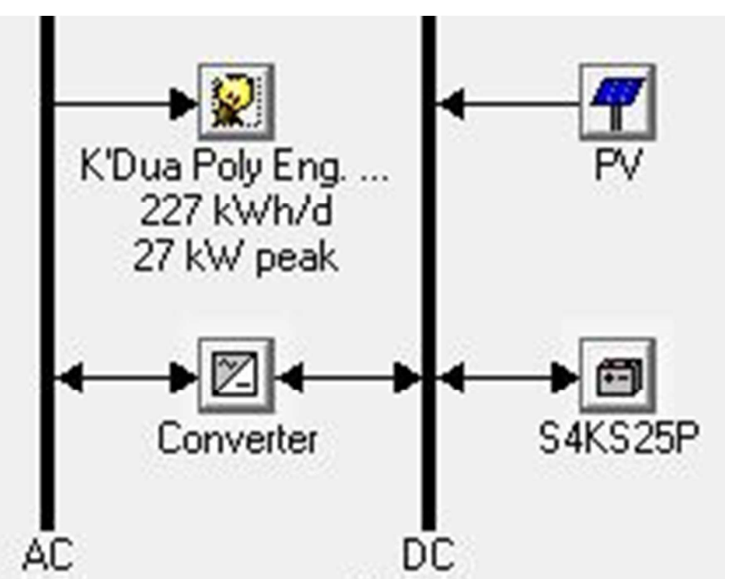

Fig. 3. Schematic of the optimized PV-system in NREL Homer. 
Based on the data collected during the site survey the proposed PV array mounting for the building is roof mount. Roof mount is appropriate as the building has enough space for the mounting of the entire 200 panels base on the GB-Sol $\mathrm{PV}$ area of $2.2 \mathrm{~m}^{2}$ and a roof area of $6671.61 \mathrm{~m}^{2}$.

\subsection{Simulation and Optimization of the System Components}

The figure above (Figure 3) shows the schematic of the design that was used to do the sensitivity analysis. In light of the load profile of the building and module efficiency, the system was optimized for several different PV array sizes ranging from 60 to $100 \mathrm{~kW}$, battery and converter. The result of an optimized two weeks PV array power, load and battery state of charge is shown in figure 4 . Three of the seven (7) days selected in the month of August require extra power as the energy generated by the system cannot meet demand resulting in shortage of power.

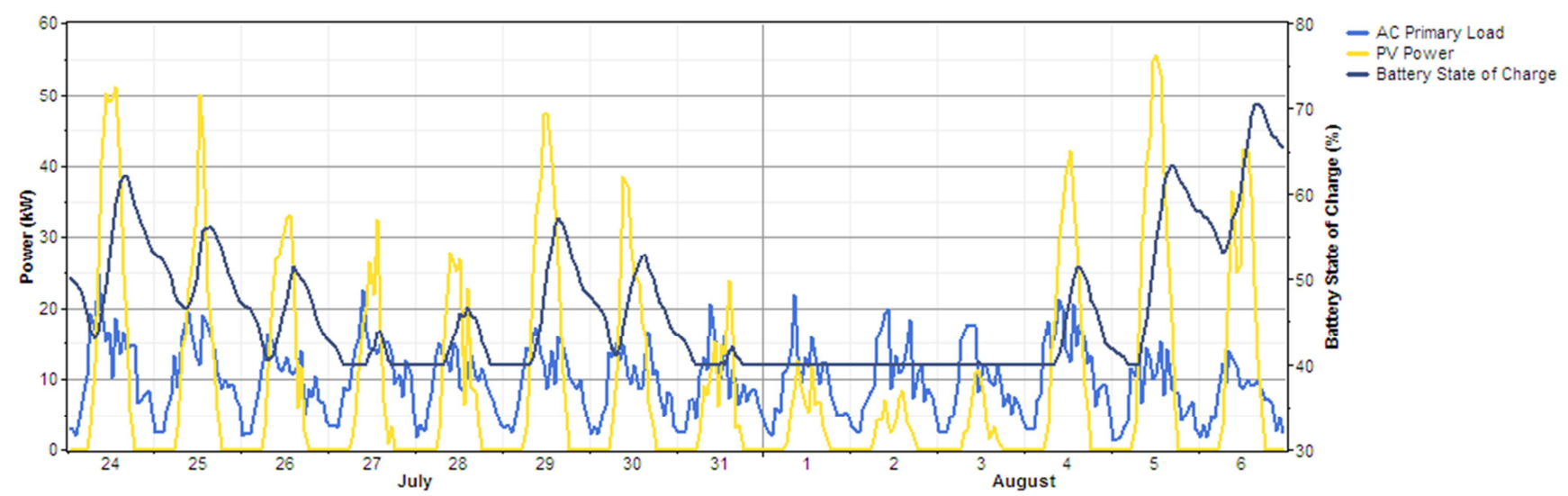

Fig. 4. Variation of power usage in the seven selected days showing PV power and load curve.

The power shortage is due to low power generation getting to the latter part of July though the power from the system matched the load quite well in that same period. This is due to the low solar radiation levels in July and August as shown in figure 1 but rather high average maximum load in the seasonal profile in figure 2. The simulated result of the electrical power production is shown in figure 5 with overall annual excess electricity of thirteen percent (13\%), unmet annual electrical load of six percent $(6 \%)$ and an annual capacity shortage of ten percent $(10 \%)$.

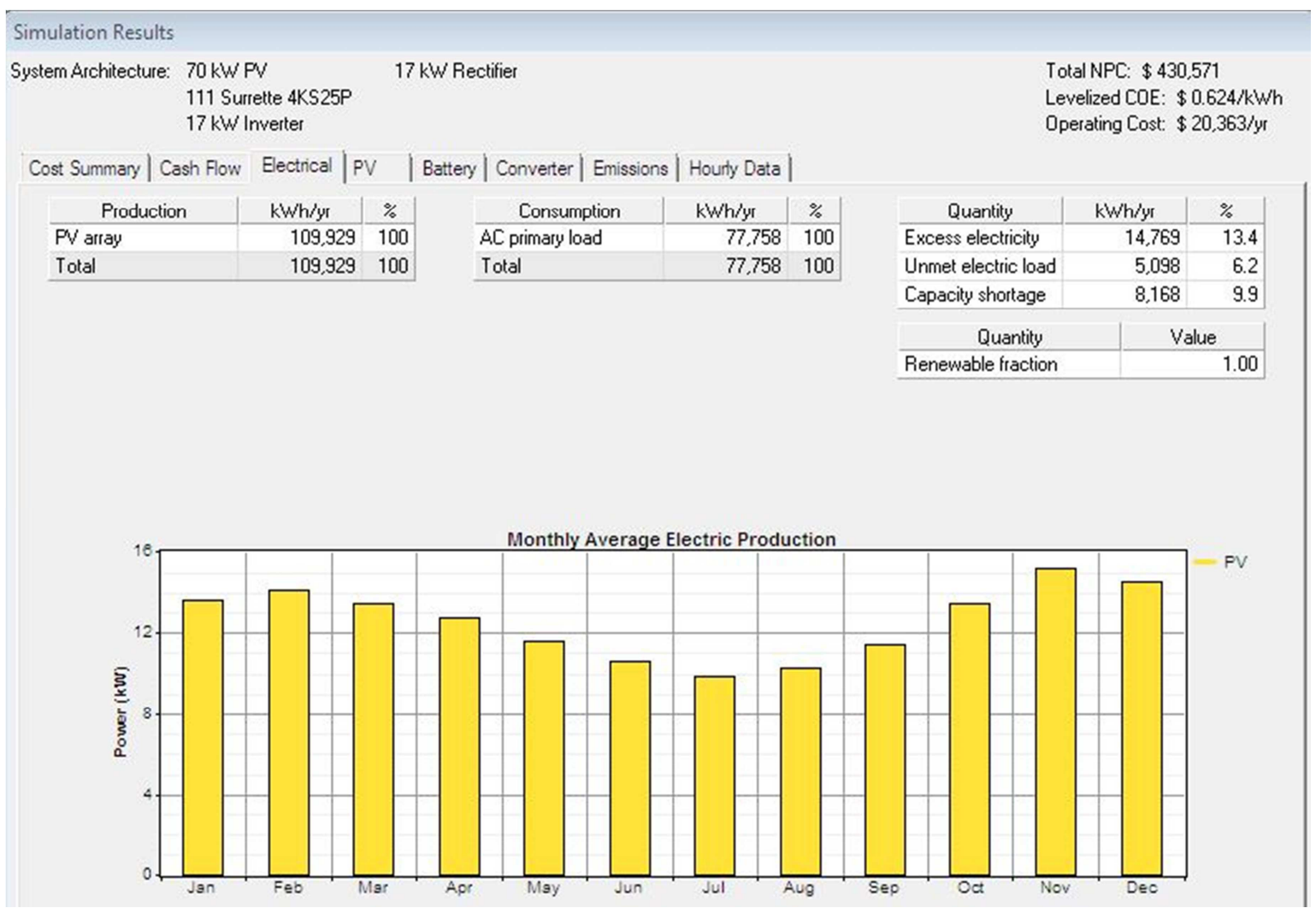

Fig. 5. Simulation results for electrical power generation in a given year. 


\subsection{The Economics of the Optimized System}

The economic analysis of the system was carried out to assess the cost and intended benefits of the project. The total investment cost comprises of the following components; module, battery, converter, mounting structures, cables and installation. Ghana has an import tax waiver on all renewable energy systems and therefore it was not factored into the calculations [13]. The costs of the various components used for the project were international prices taken from company website. Base on the average lower, middle and upper nominal interest, the inflation and currency exchange rate, three annual real interest rates of 10.3, 11.6 and 12.7 percent were computed and used in the simulation and sensitivity analysis [14]. Each of this real interest rate had a levelized cost of electricity of GHC $2.38 / \mathrm{kWh}, 2.5 / \mathrm{kWh}$ and $2.6 / \mathrm{kWh}$ respectively. These prices are above the current electricity tariff paid by institutions in the country by seventeen per cent $(17 \%)$, twenty three $(23 \%)$ and twenty eight $(28 \%)$ percent, respectively [15]. Detailed simulation results for the different average annual real interest rate can be found in appendix A3.The levelised cost of electricity in this analysis did not quantify the environmental cost associated with energy generation. For the PV system designed to reach "Grid Parity", the levelized Cost of energy should be GHC2.03/kWh. From Appendix A3 this corresponds to an annual real interest rate of six percent $(6 \%)$.

\section{Conclusion and Recommendation}

The faculty of engineering block has five floors with small variation in electric energy demand. The building has an overall average daily electrical load of $227 \mathrm{kWh}$, peak electrical load of $27 \mathrm{~kW}$ and an average electrical load of $9.48 \mathrm{~kW}$.

The designed PV system consists of $70 \mathrm{~kW}$ monocrystalline PV panel at a system voltage of $12 \mathrm{~V}$. The system has 111 batteries and $17 \mathrm{~kW}$ converter. Based on the data collected and the operational needs of the block the system designed for the block is a standalone PV-system. This system will power only the lights and fans of the block with the rest of the load being power by the grid. The roof of the building has enough space for the mounting of the PV panels with the batteries located at the ground floor. This optimized design will be able to supply hundred percent
$(100 \%)$ of the electrical load with very small computed monthly variation of about $0.734 \mathrm{~kW}$ shortage with excess electricity of $1.83 \mathrm{~kW}$ base on appendix A2.

This design is technically feasible and can help the institution contribute to the renewable energy policy agenda in the country and raise teaching and learning activities as there will be a reliable power supply to classrooms, offices and laboratories.

The economic analysis of the design reveals that the price of energy at the current rate of borrowing in the country is high compare to the current electricity prices of GHC2.03/ $/ \mathrm{kWh}$. The import duty incentive is the most widely available fiscal instruments in the country and has been used in this work. This research has shown that the annual real interest rate is high due to the nominal interest rates by banks [15].

The high cost of borrowing can be resolved by institutions and government having special interest rate of six percent $(6 \%)$ for investments in renewable energy technologies. As governments around the world are quantifying the environmental cost associated with energy generation as a form of fiscal instruments, the government can look at such initiatives to serve as an additional income to investors in renewable energy technologies. Also, government should encourage institutions whose energy consumption is above a certain threshold to incorporate renewable energy in their consumption mix by providing interest free loans or soft loans to such institutions [16].

Also, the maintenance cost can be brought down by using the expertise of the energy systems department and students to expose them to the real world industrial projects in renewable energy technologies.

Also as an academic institution offering training in renewable energy programs, it will enhance its academic credentials and boost the image of the institution and also set the pace for similar projects and research to be carried out in other institutions.

Further studies should be carried out to identify and establish institutions that have financial policy towards green investment and also quantifying the environment cost associated with energy generation in Ghana.

\section{Appendix}

Appendix A1

Table A1. Load profile for ground floor lights and fans.

\begin{tabular}{|c|c|c|c|c|c|c|c|c|c|c|c|}
\hline $\begin{array}{l}\text { Classification } \\
\text { of the block }\end{array}$ & $\begin{array}{l}\text { Number of } \\
\text { rooms }\end{array}$ & $\begin{array}{l}\text { number of } \\
\text { bulbs/ room }\end{array}$ & $\begin{array}{l}\text { total } \\
\text { quantity } \\
\text { of bulb }\end{array}$ & wattage & $\begin{array}{l}\text { Duration of } \\
\text { usage (Hrs/day) }\end{array}$ & E.C & $\begin{array}{l}\text { number of } \\
\text { fans/room }\end{array}$ & $\begin{array}{l}\text { total } \\
\text { quantity }\end{array}$ & wattage & $\begin{array}{l}\text { Duration } \\
\text { of usage } \\
\text { (Hrs/day) }\end{array}$ & E.C \\
\hline Offices & 3 & 3 & 9 & 20 & 8 & 1440 & 2 & 6 & 50 & 8 & 2400 \\
\hline Lab & 2 & 18 & 36 & 20 & 8 & 5760 & 12 & 24 & 50 & 7 & 8400 \\
\hline Corridor & 1 & 23 & 23 & 20 & 4 & 1840 & 0 & 0 & & 4 & 0 \\
\hline Archives & 1 & 6 & 6 & 20 & 2 & 240 & 0 & 0 & & 2 & 0 \\
\hline Washroom & 3 & 3 & 9 & 20 & 8 & 1440 & 0 & 0 & & 8 & 0 \\
\hline Workshop & 1 & 10 & 10 & 20 & 8 & 1600 & 0 & 0 & & 8 & 0 \\
\hline \multirow[t]{2}{*}{ Store room } & 2 & 2 & 4 & 20 & 2 & 160 & 0 & 0 & & 2 & 0 \\
\hline & & & & & Total & 12480 & & & & Total & 10800 \\
\hline
\end{tabular}


Table A2. Load profile for first floor lights and fans.

\begin{tabular}{|c|c|c|c|c|c|c|c|c|c|c|c|}
\hline $\begin{array}{l}\text { Classification } \\
\text { of the block }\end{array}$ & $\begin{array}{l}\text { Number of } \\
\text { rooms }\end{array}$ & $\begin{array}{l}\text { number of } \\
\text { bulbs/ room }\end{array}$ & $\begin{array}{l}\text { total } \\
\text { quantity of } \\
\text { bulb }\end{array}$ & wattage & $\begin{array}{l}\begin{array}{l}\text { Duration } \\
\text { of usage } \\
\text { (Hrs/day) }\end{array} \\
\end{array}$ & E.C & $\begin{array}{l}\text { number } \\
\text { of fans }\end{array}$ & $\begin{array}{l}\text { total } \\
\text { quantity }\end{array}$ & wattage & $\begin{array}{l}\text { Duration of } \\
\text { usage } \\
\text { (Hrs/day) }\end{array}$ & E.C \\
\hline Offices & 10 & 3 & 30 & 20 & 15 & 9000 & 2 & 20 & 50 & 14 & 14000 \\
\hline $\begin{array}{l}\text { Conference } \\
\text { room }\end{array}$ & 2 & 18 & 36 & 20 & 15 & 10800 & 12 & 24 & 50 & 13 & 15600 \\
\hline Corridor & 1 & 23 & 23 & 20 & 4 & 1840 & 0 & 0 & & 4 & 0 \\
\hline Washroom & 3 & 3 & 9 & 20 & 8 & 1440 & 0 & 0 & & 8 & 0 \\
\hline \multirow[t]{2}{*}{ Store room } & 2 & 2 & 4 & 20 & 2 & 160 & 0 & 0 & & 2 & 0 \\
\hline & & & & & total & 23240 & & & & Total & 29600 \\
\hline
\end{tabular}

Table A3. Load profile for fourth floor.

\begin{tabular}{|c|c|c|c|c|c|c|c|c|c|c|c|}
\hline $\begin{array}{l}\text { Classification } \\
\text { of the block }\end{array}$ & $\begin{array}{l}\text { Number } \\
\text { of rooms }\end{array}$ & $\begin{array}{l}\text { number of } \\
\text { bulbs/ room }\end{array}$ & $\begin{array}{l}\text { total } \\
\text { quantity of } \\
\text { bulb }\end{array}$ & wattage & $\begin{array}{l}\text { Duration of } \\
\text { usage } \\
\text { (Hrs/day) }\end{array}$ & E.C & $\begin{array}{l}\text { number } \\
\text { of fans }\end{array}$ & $\begin{array}{l}\text { total } \\
\text { quantity }\end{array}$ & wattage & $\begin{array}{l}\text { Duration of } \\
\text { usage } \\
\text { (Hrs/day) }\end{array}$ & E.C \\
\hline Offices & 12 & 3 & 36 & 20 & 8 & 5760 & 2 & 14 & 50 & 8 & 5600 \\
\hline Labs & 4 & 18 & 72 & 20 & 8 & 11520 & 10 & 24 & 50 & 8 & 16000 \\
\hline Corridor & 1 & 23 & 23 & 20 & 4 & 1840 & 0 & 0 & & 4 & 0 \\
\hline Washroom & 3 & 3 & 9 & 20 & 8 & 1440 & 0 & 0 & & 8 & 0 \\
\hline \multirow[t]{2}{*}{ Store room } & 2 & 2 & 4 & 20 & 2 & 160 & 0 & 0 & & 2 & 0 \\
\hline & & & & & Total & 20720 & & & & Total & 25600 \\
\hline
\end{tabular}

\section{Appendix $A 2$}

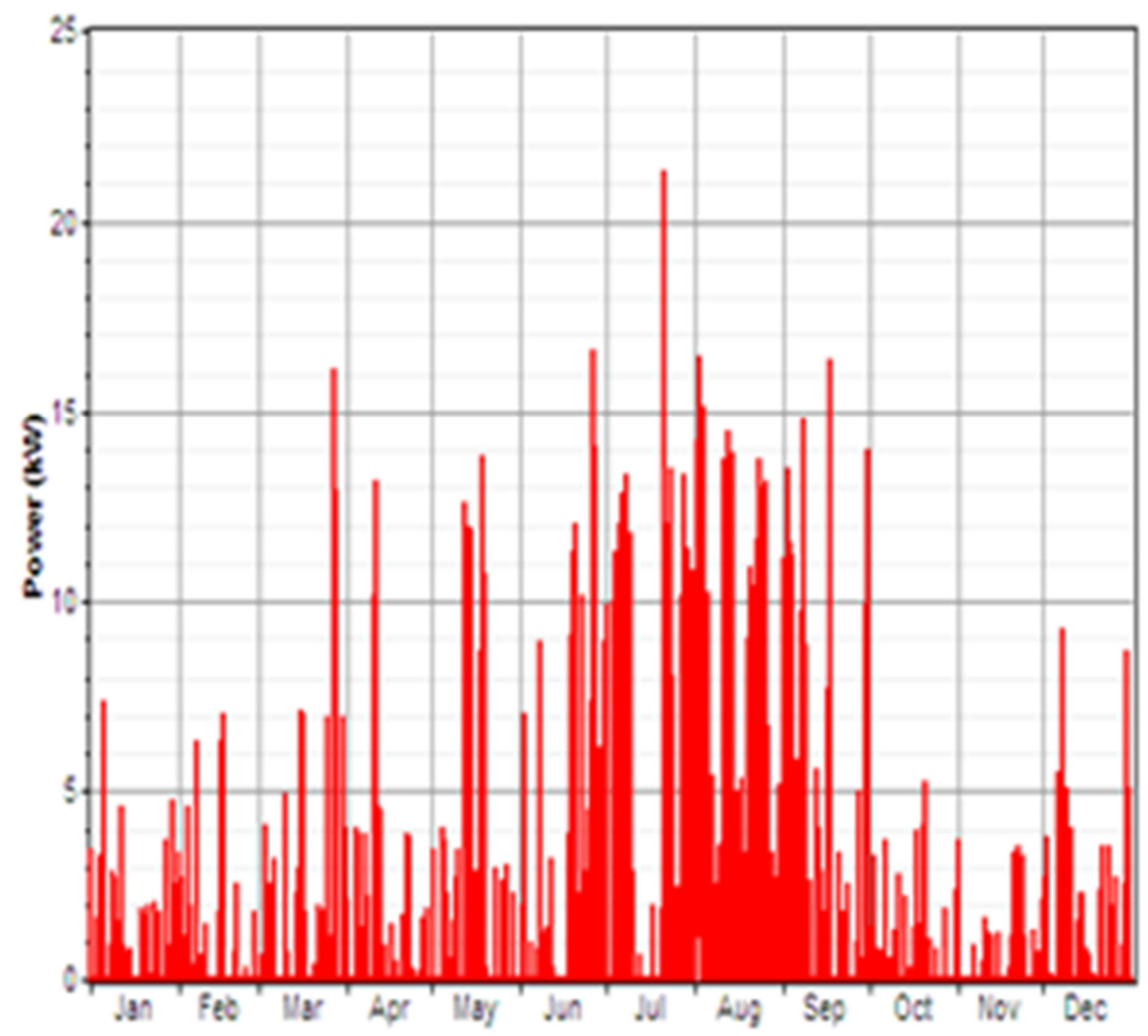

Fig. A1. Unmet electrical load monthly averages. 


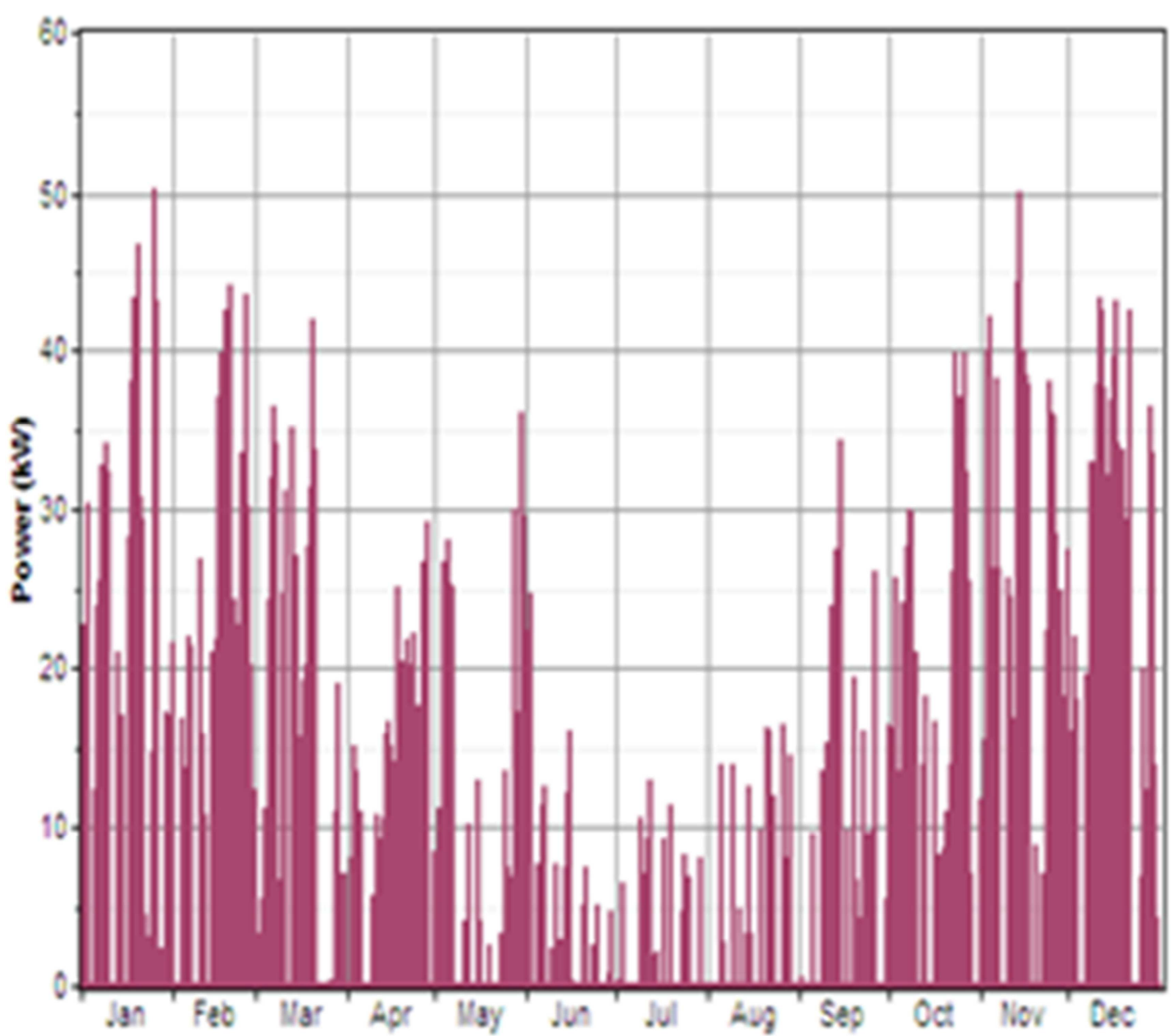

Fig. A2. Excess electrical production monthly averages.

\section{Appendix A3}

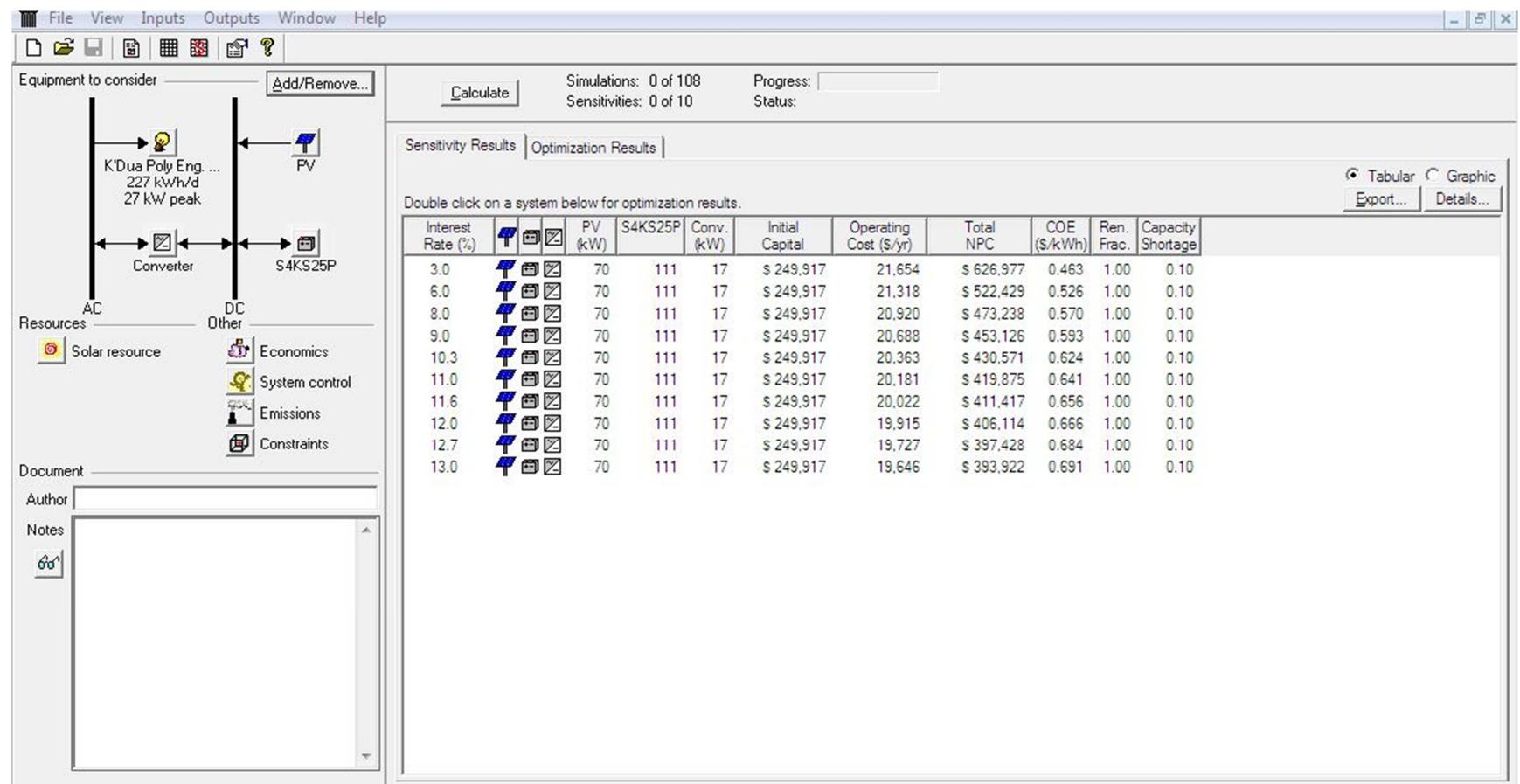

Fig. A3. Simulation results for different interest rates. 


\section{References}

[1] Ghana Energy Commission. (2015). National Energy statistics 2005-2014. Strategic planning and policy division, Energy commission of Ghana. Available at: http//www.energycom.gov.gh/files/ENERGY\%20STATISTIC S.pdf accessed on 15/01/2016.

[2] Brew-Hammond A., et al (2007). Energy crises in Ghana: Drought, Technology or Policy? KNUST, Kumasi, Ghana, ISBN: 9988-8377-2-0. Pp23-43.

[3] SWERA National Report. Available at $\mathrm{http} /$ www.energycom.gov.gh/downloads/Technical\%20Report s/SWERA $\% 20 \%$ National\%20Report.pdf accessed on 10/02/2016.

[4] National Renewable Energy Laboratory (NREL): HOMER, the Micropower Optimization Model [Online]. Available at: http://www.homerenergy.com.

[5] Martinot, E., (2001) Renewable energy investment by the world bank. Energy Policy, 29, 689-699.

[6] Energy Commission of Ghana (2006). Strategic national energy plan 2006-2020 and Ghana Energy Policy. Main version, Energy Commission of Ghana.

[7] Ministry of Energy and Petroleum (2014). Renewable Energy Policy issues / Energy Act 2011, Act 832(01).

[8] Institute of Statistical, Social and Economic Research (2005). Guide to electric power in Ghana. University of Ghana,. Pg $17-23$

[9] Ministry of Energy and Petroleum (2014) Medium term expenditure framework (MTEF) for 2014-2016. Programme based budget estimates. MoEP.

[10] VRA 2MW Solar Power Plant at Novrongo available at http://www.vra.com/our_mandate/solar_energy.php accessed on $30 / 11 / 2016$.

[11] GB-Sol Ltd. Solar PV Specifications Available at: http://www.gb-sol.co.uk/wp-content/uploads/2015/05/GBS330-360-Datasheet.pdf accessed on 10/12/2015.

[12] Qingdao solar leading. Converter specification Available at: http://www.solarleading.com accessed on 19/10/2015.

[13] Tariff structure for imports (2013). Available at http://www.ghanaweb.com/GhanaHomePage/economy/import _duty.php accessed on 28/08/2015.

[14] Bank of Ghana (2016). Interest rate and inflation. Available at: http://www.bog.gov.gh accessed on 15/01/2016.

[15] Electricity Company of Ghana. Electricity Prices. Available at: http//www.ecgonline.info/images/RECKONER_Poster.pdf Accessed on 14/04/2016.

[16] NEPAD Business Investment Guide. Renewable energy: Carbon Finance and Africa's Energy Challenge. Corporate Africa (2008) (4). 